\title{
XXXVI. Method of obviating the necessity of lifting ships
}

\section{Mr. Robert Seppings}

To cite this article: Mr. Robert Seppings (1805) XXXVI. Method of obviating the necessity of lifting ships, Philosophical Magazine Series 1, 22:87, 242-247, DOI: 10.1080/14786440508562449

To link to this article: http://dx.doi.org/10.1080/14786440508562449

曲 Published online: 18 May 2009.

Submit your article to this journal $\sqsubset \pi$

Џ Article views: 2

Q View related articles $\sqsubset$ 


\section{$[242]$}

XXXVI. Method of olviating the Necessity of lifting Ships. By Mr. Ro8ert Seppings, of Chatham Yard*.

\section{T} HE following is a description of an invention by $\mathrm{Mr}$. Robert Seppings, late master shipwright assistant in his majesty's yard at Plymouth (now master shipwright at his majesty's yard, Chatham), for suspending, instead of Jifting, ships, for the purpose of clearing them from their blocks, by which a very great saving will accrue to the public, and also two-thirds of the time formerly used in this operation.

From the saving of time another very important advantage is derived, namely, that of enabling large ships to be docked, suspended, and undocked, the same spring tides. Without enumerating the inconveriencies arising, and, perhaps, injuries, which ships are liable to sustain, from the former practice of lifting them, and which are removed by the present plan; that which relates to manual labour deserves particular attention; twenty men being sufficient to suspend a first-rate, whereas it would require upwards of 500 to lift her. The situation which Mr. Seppings held in Plymouth-yard, attached to him, in a great degree, the shoring and lifting of ships, as well as the other practical part of the profession of a shipwright. Here he had an opportunity of observing, and indeed it was a subject of general regret, how much time, expense, and labour, were required in lifting a ship, particularly ships of the line. This induced him to consider whether some contrivance could not be adopted to obviate these evils. And it occurred to him, that if he cauld so construct the blocks on which the ship rests, that the weight of the ship might be applied to assist in the operation, he should accomplish this very desirable end. In September 1800 , the shoring and lifting the San Josef, a large Spanish first-rate, then in dock at Plymouth, was committed to his directions; to perform whtch, the assistance of the principal part of the artificers of the yard was requisite. In conducting this business, the plan, which will be hereafter described, occurred to his mind; and from that time, he, by various experiments, proved his theory to be correct: the blocks, constructed by him, upon which the ship rests, being so contrived, that the facility in removing them, is proportionate to the quantity of pressure; and this circumstance is always absolutely

* From the Transartions of the Socisty of Arts, who voted him the gold medal, 1804.

under 
under command, by increasing or diminishing the angle of three wedges, which constitute one of the blocks; two of which are horizontal, and one vertical. By enlarging the angle of the horizontal wedges, the vertical wedge becomes of consequence more acute; and its power may be so increased, that it shall have a great tendency to displace the horizontal wedges, as was proved by a model, which accompanied the statement to the society; where the power of the screw is used as a substitute for the pressure of the ship.

Mr. Seppings caused three blocks to be made of hard wood agreeable to his invention, and the wedges of various angles. The horizontal wedges of the first block were nine degrees; of the second, seven; and of the third, five; of course, the angle of the vertical wedge of the first block was 162 degrees; of the second, 166; and of the third, 170 . These blocks, or wedges, were well executed, and rubbed over with soft soap for the purpose of experiment. They were then placed in a dock, in his majesty's yard, at Plymouth, in which a sloop of war was to be docked: on examining them after the vessel was in, and the water gone, they were all found to have kept their situations, as placed before the ship rested upon them. Shores in their wake were then erected to sustain the ship, prior to the said blocks being taken from under the keel. The process of clearing them was, by applying the power of batteringrams to the sides of the outer ends of the horizontal wedges; alternate blows being given fore and aft; by which means they immediately receded, and the vertical wedges were disengaged. It was observed, even in this small ship, that the block. which was formed of horizontal wedges of nine degrees, came away much easier than those of seven, and the one of seven than that of five. In removing the aforesaid blocks by the power of the battering-rams, which were suspended in the hands of the men employed, by their holding ropes passed through holes for that purpose, it was remarked by Mr. Seppings, that the operation was very laborious to the people; they having to support the weight of the battering-rams, as well as to set them in motion. He then conceived an idea of affixing wheels near the extremity of that part of the rams which strikes the wedges. This was done before the blocks were again placed; and it has since been found fully to answer the purpose intended, particularly in returning the horizontal wedges to their original situations, when the work is performed for which they were displaced; the wheels also giving a great increase of Q 2 
power to the rams, and decrease of labour to the artificers; besides which, the blows are given with much more exactness. The same blocks were again laid in another dock, in which a two-decked ship of the line was docked. On examination they were found to be very severely pressed, but were removed with great ease. They were again placed in another dock in which a three-decked ship of the line was docked. This ship having in her foremast and bowsprit, the blocks were put quite forward, that being the part which presses them with the greatest force. As soon as the water was out of the dock, it was observed that the horizontal wedges of nine and seven degrees had receded some feet from their original situations. This afforded Mr. Seppings a satisfactory proof, which experience has since demonstrated (though many persons before would not admit of, and others could not understand, the principle), that the facility of removing the blocks or wicdges, was proportionate to the quantity of pressture upon them: The block of five degrees kept its place, but was immediately cleared, by applying the power of the battering-rams to the sides of the outer ends of the horizontal wedges. The above experiments being communicated to the Navy Board, Mr. Seppings was directed to attend them, and explain the principle of his invention; which explanation, further corroborated by the testimonials of his then superior officers, was so satisfactory, that a dock was ordered to be fitted at Plymouth under his immediate directions. The horizontal wedges in this, and in the other docks, that were afterwards fitted by him, are of cast iron, with an angle of about five degrees and a half, which, from repeated trials, are found equal to any pressure, having in no instance receded, and, when required, were easily removed. The vertical wedge is of wood, lined with a plate of wrought iron, half an inch thick. On the bottom of the dock, in the wake of each block, is a plate of iron of three quarters of an inch thick, so that iron at all times acts in contact with iron.

The placing the sustaining shores, the form and sizes of the wedges, and battering-rams, \&cc.; also the process of taking away, and again replacing, the wedgcs of which the block is composed, are also exemplified by a model.

The dock being prepared at Plymouth, in August 1801 the Canopus, a large French 80-gun ship, was taken in, and rested upon the blocks; and the complete success of the experiment was such, that other docks were ordered to he fitted at Sheerness and Portsmouth dock-yards, under Mr. Seppings's directions. At the former place a firgate, 
and at the latter a three-decked ship, were suspended in like manner. This happened in December 1809, and January 1803 ; and the reports were so favourable, as to cause directions to be given for the general adoption of these blocks in his majesty's yards. This invention being thought of national consequence, with respect to skips, but particularly those of the navy, government has boen pleased to notice and reward Mr. Seppings for it.

The time required to disengage each block is from one to three minutes after the shores are placed: and a first-rate sits on about fifty blocks. Various are the causes for which a ship may be required to be cleared from her blocks, viz. to shift the main keel; to add additional fasle keel ; to repair defects ; to caulk the garboard seams, scarples of th keel, \&cc. Imperfections in the false keel, which are so very injurious to the cables, can, in the largest ship, be remedied in a few hours by this invention, without adding an additional shore, by taking away blocks forward, amidships, and abaft, at the same time; and, when the keel is repaired in the wake of those hlocks, by returning them into their places, and then by taking out the next, and so on in succession. The blocks can be replaced in their original situations, by the application of the wheel batteringrams to the wedges, the power of which is so very great, that the weight of the ship can be taken from the shores that were placed to sustain her. There were one hundred and six ships of different classes, lifted at Plymouth dockyard, from the ist of January 1798 to the 31 st of December 1800; and, had the operation of lifting taken less time, the number would have been very considerably increased; for the saving of a day is very frequently the cause of saving a spring tide, which makes the difference of a fortnight. The importance of this expedition, in time of war, cannot be sufficiently estimated.

This invention may be applied with great advantage, whenever it is necessary to erect shores, to support any great weights, as, for instance, to prop up a building during the repair of its foundation, \&c. Captain Wells, of his majesty's ship Glory, of 98 guns, used wedges of Mr. Seppings's invention for a fid of a top-gallant mast of that ship. In 1803, the top-gallant masts of the Defence, of 74 guns, were fitted on, this principle by Mr. Seppings : and, from repeated trials, since she has been cruizing in the North Sea, the wedge fids have been found in every respect to answer.

But it is Mr. Seppings's wish that it should be underQ 3 stood, 
stood, that the idea of applying this invention to the fid of a top-gallant mast originated with captain Wells, who well understood the principle, and had received from him a model of the invention.

When it is required to strike a top-gallant mast, the top ropes are hove tight, and the pin which keeps the horizontal wedges in their place is taken out, by one man going aloft for that purpose; the other horizontal wedge is worked in the fid, as shown in the drawing and model that accompany this statement. The upper part of the fid hole is cut to form the vertical wedge. The advantage derived from fidding top-gallant masts in this way is, that they can be struck at the shortest notice, and without slacking the rigging, which is frequently the cause of springing and carrying them away, particularly those with long pole heads. The angle of the horizontal werlges for the fids of masts should be about twenty degrees.

The above account was accompanied with certificates from sir John Henslow, surveyor of the navy; Mr. M. Didram, master-shipwright of Portsmouth-yard; and Mr. John Carpenter, foreman of Shetrness dock-yard, confirming Mr. Seppings's statement.

\section{Reference to the Engraving of Mr. Seppings's method of olviating the necessity of lifting ships. Plate IV.}

This plan and section of a seventy-four gun ship describes the method of obviating the necessity of lifting ships, when there may be occasion to put additional false keels to them, or to make good the imperfections of those alreaty on; also, when it may be necessary, to caulk the garboard seams, scarples, the keel, \&c.; by which means a very considerable part of the expense will be saved, and much time gained. The blocks are cleared, and again returned by the following process. A sufficient number of shores are placed under the ship to sustain her weight, and set taught, stationed as near the keel as the working of the batteringrams fore and aft will admit. Avoid placing any orposite the blocks, as they would in that case hinder the return of the wedges with the battering-rams. A blow must then be given forward on the outer end of the iron wedges with the battering-rams in a fore and aft direction, which will cause them to slide aft, as shown in the plan. The battering-rams abaft then return the blow, and the wedges again come forward; by the repetition of this operation, the wedges will be with great ease cleared, and the angular 


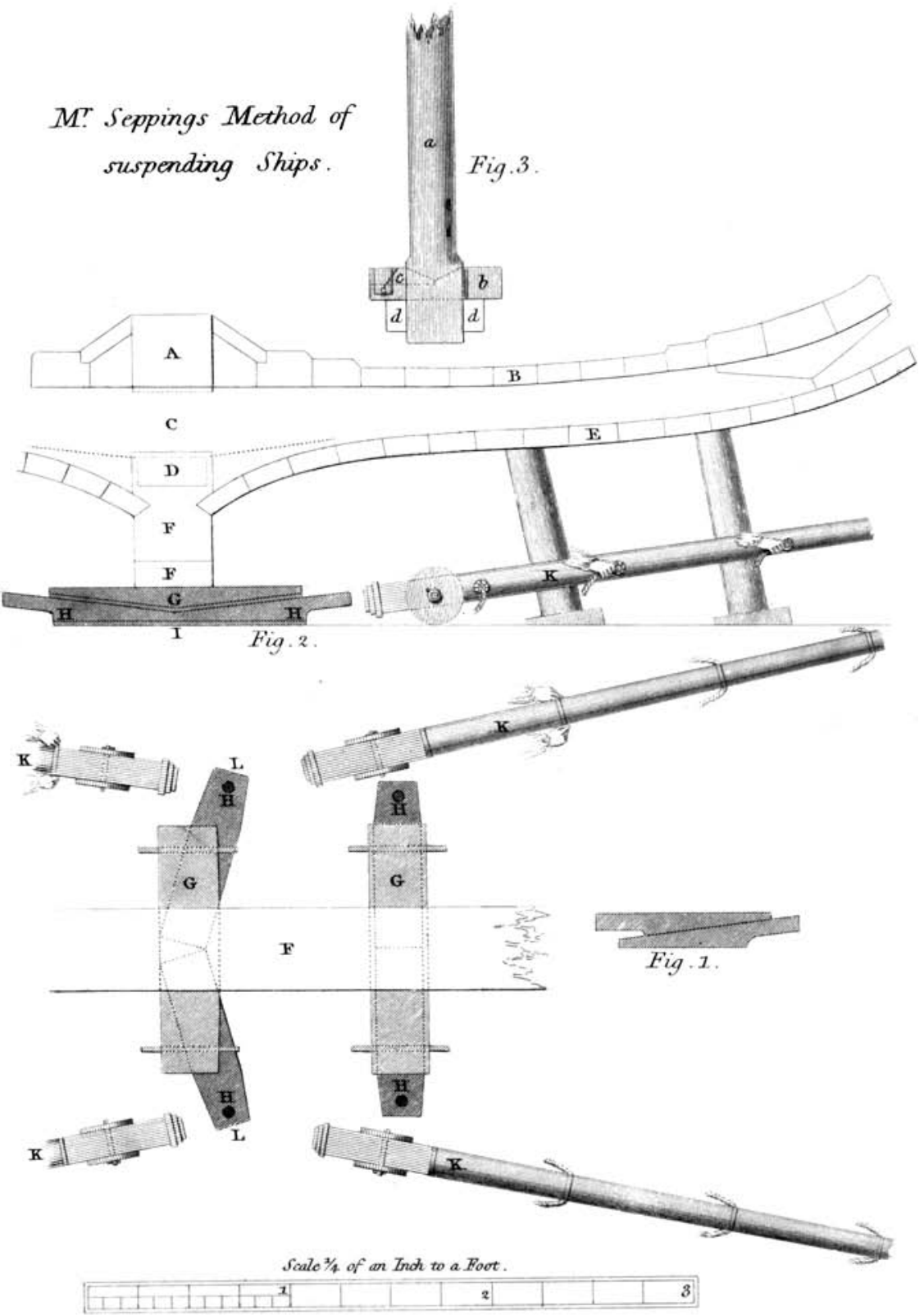


block on the top will drop down. When the work, is performed, the block must be replaced under the keel, and the wedges driven back by working the rams athwart-ships, as described in the section.

N. B. In returning the iron wedges, to avoid straining the angular blocks, it is proposed to leave a few of them out forward and aft, and stop the ship up, by laying one iron wedge on the other, as shown at Fig. 1, Plate IV.

To facilitate the business, blocks may be cleared forward and aft at the same time, sufficient to get in place one length of false keel. If the false keel should want repairing, it may bedone without any additional shores, by clearing one block at a time; and when the keel is repaired in the wake of that block, return the wedges, as above directed, and clear the next, \&xc.

Section and Plan, Plate IV. Fig. 2.

A, Keelson.

$\mathbf{B}$, Ceiling.

C, Floor timber.

$\mathrm{D}$, Dead or rising wood.

E, Plank of the bottom.

$F$, Keel and false keel. them.

$G$, Angular blocks with a half-inch iron-plate bolted to

$\mathbf{H}$, Cast-iron wedges.

I, Iron-plate of three-fourths of an inch thick on the bottom of the dock.

$K$, Battering-rams, with wheels, and ropes for the hands.

L, Cast-iron wedges, having received a blow from forward.

M, Shores under the ship to sustain her weight.

Fig. 3. represents part of a top-gallant mast fitted with 2 wedge fid.

$a$, Top-gallant mast.

$\mathfrak{l}$, Fid, with one horizontal wedge worked on it.

c, Moveable wedge, with the iron strap and pin over it,

to keep it in its situation,

$d$, Trussel trees. 